\title{
Keanekaragaman Jenis Keong Darat di Taman Wisata Alam Telaga Warna, Bogor, Jawa Barat
}

\section{Diversity of land conch in Telaga Warna Natural Tourism Park, Bogor, West Java}

\author{
Widia Andiani Wijaya ${ }^{1}$, Paskal Sukandar ${ }^{1}$, Meitiyani $^{{ }^{*}}$ \\ ${ }^{1}$ Program Studi Pendidikan Biologi, FKIP UHAMKA Jalan Tanah Merdeka, DKI Jakarta, 13650 \\ *Email Korespondensi: meitiyani@uhamka.ac.id \\ doi: http://dx.doi.org/10.29405/j.bes/318-153161
}

Received: 23 Februari 2019 | Accepted: 05 Juni 2019 | Published: 27 Juni 2019

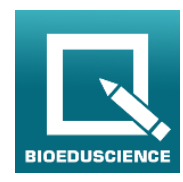

Abstrak

Background: Keong darat memiliki peranan yang penting dalam sebuah ekosistem tanah. Penelitian ini bertujuan untuk menghitung keanekaragaman jenis keong darat di Kawasan Taman Wisata Alam (TWA) Telaga Warna Puncak Bogor Jawa Barat. Metode: Purposive sampling digunakan dalam penelitian ini yaitu menentukan lokasi penelitian, dengan memasang transek garis dan memasang kuadrat. Lokasi penelitian yaitu hutan primer, hutan sekunder dan sekitar danau di Kawasan Taman Wisata Alam Telaga Warna (TWA). Hasil: Hasil penelitian menunjukan keaneakaragaman jenis keong darat tertinggi pada waktu malam hari dari ketiga lokasi berada di lokasi hutan primer dengan nilai $\mathrm{H}^{\prime}=1.76, \mathrm{E}=0.90$ dan memiliki dominansi terendah $\mathrm{C}=0.15$. Sedangkan keanekaragaman terendah berada di lokasi sekitar danau H' = $0.55, \mathrm{E}=0.50$ dan memiliki dominansi tertinggi $\mathrm{C}=0.64$. Keanekaragaman jenis pada waktu pagi hari yang tertinggi dari ketiga lokasi dekat danau dengan nilai $\mathrm{H}^{\prime}=0.94, \mathrm{E}=0.85$ dan memiliki dominansi terendah $\mathrm{C}$ $=0.44$. Sedangkan keanekaragaman terendah di lokasi hutan sekunder dengan nilai $\mathrm{H}^{\prime}=0.52, \mathrm{E}=0.37$ dan memiliki dominansi tertinggi $\mathrm{C}=0.72$. Kesimpulan: Pola sebaran pada waktu malam hari di ketiga lokasi memiliki pola sebaran seragam yaitu hutan primer, hutan sekunder, sedangkan dekat danau pola sebaran jenis individu acak dan pola sebaran pada pagi hari di ketiga lokasi yaitu hutan primer dan dekat danau seragam sedangkan pada hutan sekunder pola sebaran mengelompok. keanekaragaman jenis keong darat di Kawasan Taman Wisata Alam (TWA) Telaga Warna tergolong sedang.

Kata kunci: Keanekaragaman; Keong Darat; Taman Wisata Alam (TWA); Telaga Warna.

\section{Abstract}

Background: Eclipta prostrata, Synedrella nodiflora, and Tridax procumbens were found growing wild on the side of Bogor Highway. The study was conducted to determine the concentration of Pb and $\mathrm{Cd}$ in the soil, roots, and shoots (aerial parts) of E. prostrata, S. nodiflora, and T. procumbens which grew wild on the side of the Bogor Highway, and to study the phytoremediation mechanism in the three plants as phytoremediator candidate. Methods: Analysis of $\mathrm{Pb}$ and $\mathrm{Cd}$ content in the soil and plants was carried out with Atomic Absorption Spectrophotometry AAS. Soils and plants sampling was performed by purposive sampling technique. Results: The concentrations of $\mathrm{Pb}$ and $\mathrm{Cd}$ in the soil ranged from 2.72-103.38 $\mathrm{mg} / \mathrm{kg}$ for $\mathrm{Pb}$ and were not detected up to $0.08 \mathrm{mg} / \mathrm{kg}$ for $\mathrm{Cd}$. The highest $\mathrm{Pb}$ concentration in the roots of $E$. prostrata, S. nodiflora and, T. procumbens were $17.79 \mathrm{mg} / \mathrm{kg}, 14.53 \mathrm{mg} / \mathrm{kg}$, and $62.14 \mathrm{mg} / \mathrm{kg}$, while in successive shoots $4,91 \mathrm{mg} / \mathrm{kg}, 8.84 \mathrm{mg} / \mathrm{kg}$, and $6.08 \mathrm{mg} / \mathrm{kg}$ respectively. The highest concentration of Cd in the roots of E. prostrata, $S$. nodiflora and T. procumbens were respectively $0.56 \mathrm{mg} / \mathrm{kg}, 0.23 \mathrm{mg} / \mathrm{kg}$, and $0.26 \mathrm{mg} / \mathrm{kg}$, while in buds respectively $0,29 \mathrm{mg} / \mathrm{kg}, 0.25 \mathrm{mg} / \mathrm{kg}$, and $0.45 \mathrm{mg} / \mathrm{kg}$. Conclusions: Based on TF, $B C F$ and BAF values from the three plants, the phytoremediation mechanisms that tend to be used by E. prostrata, S. nodiflora, and T. procumbens for Pb absorption, and E. prostrata and S. nodiflora for Cd absorption are phytostabilization, while T. procumbens against Cd metal is potentially used for phytoextraction

Keywords: Diversity; Gastropoda Terrestrial; Ragional Nature Park; Telaga Warna.

Cara citasi: Wijaya, W.A., Sukandar, P. Meitiyani, M. (2019). Keanekaragaman jenis keong darat di Taman Wisata Alam Telaga Warna, Bogor, Jawa Barat. BIOEDUSCIENCE: Jurnal Pendidikan Biologi dan Sains, 03(1): 14-22. Doi: http://dx.doi.org/10.29405/j.bes/318-153161 
(C) 2019 Oleh authors. Lisensi Bioeduscience, Uhamka, Jakarta. Artikel ini bersifat open access yang didistribusikan di bawah syarat dan ketentuan Creative Commons Attribution (CC BY) license. (http://creativecommons.org/licenses/by/4.0/).

\section{PENDAHULUAN}

Keong merupakan nama umum yang digunakan untuk merujuk sejumlah siput laut beserta cangkangnya, dari yang berukuran sedang hingga berukuran besar. Ada berbagai macam cangkang di seluruh dunia dengan berbagai bentuk, dan masing-masingnya adalah kerangka luar, dan sekaligus rumah, hewan, untuk keperluan kita laut. Dari semua cangkang dunia, tidak termasuk bivalvia (kerang, kerang, kerang, tiram, dll), cephalopoda (nautilus, sotong) dan yang lainnya, hanya satu jenis yang menjadi perhatian kita di sini, yaitu gastropoda (Cunha \& Migotto, 2015).

Gastropoda adalah salah satu kelompok hewan yang paling beragam, baik dalam bentuk, kebiasaan, maupun habitat (Manutchehr-Danai, 2009). Sejauh ini mereka adalah kelompok moluska terbesar, dengan lebih dari 75.000 spesies yang hidup, dan mereka terdiri dari sekitar $80 \%$ moluska hidup. Perkiraan total spesies yang masih ada berkisar dari 40.000 hingga lebih dari 100.000. Tetapi mungkin ada sebanyak 150.000 spesies! Ada sekitar 13.000 genera fosil untuk gastropoda sampai saat ini. Mereka memiliki catatan fosil yang panjang dan kaya dari Kambrium Awal yang menunjukkan kepunahan subclade secara berkala, diikuti dengan diversifikasi kelompok baru (Jeffery, 2001).

Peranan keong darat dimanfaatkan sebagai indikator untuk mengetahui hutan yang masih mendekati asli atau sudah mengalami perubahan (Kozminsky, 2012). Keong darat adalah hewan yang amat sensitif terhadap perubahan lingkungan, hal ini berkaitan dengan struktur tubuh keong yang berkulit tipis dan lembut membutuhkan lingkungan yang amat spesifik terutama kelembaban tinggi dengan suhu yang relatif rendah adalah hutan yang memiliki vegetasi padat bertajuk rapat sehingga mampu menahan penguapan dan menyimpan air di dalamnya (Heryanto, 2012).

Salah satu hutan konservasi yang dimiliki kawasan Puncak Bogor Jawa Barat adalah Cagar Alam Telaga Warna. Cagar Alam Telaga Warna merupakan Cagar Alam yang berada di kawasan tropis yang sangat vital fungsinya sebagai paruparu dunia, baik sebagai penyerap dan penyimpan karbon, maupun sebagai penghasil oksigen. Cagar Alam Telaga Warna telah mengalami perubahan dari habitat aslinya yaitu, peralihan fungsi lahan hutan konservasi menjadi hutan wisata yang dikenal dengan Taman Wisata Alam Telaga Warna

Kawasan Taman Wisata Alam (TWA) Telaga Warna memiliki luas $5 \mathrm{Ha}$, berdasarkan Surat Keputusan Menteri Pertanian No. 481/KPTS/UM/6/1981. Kawasan Taman Wisata Alam memiliki flora dan fauna yang beragam, diantaranya terdapat jenis tumbuhan yang sudah langka dan dilindungi oleh undang-undang seperti Kiaksara (Macodes petola) dan Perut (Banophora). Di TWA terdapat hewan yang masih terjaga populasinya seperti monyet ekor panjang, lutung, burung dan keong. Taman Wisata Alam memiliki lokasi yang merupakan perbatasan dengan Cagar Alam yaitu hutan primer dan hutan sekunder yang masih terjaga kerapatan vegetasinya.

Namun, di hutan sekunder sudah mulai beralih fungsi dengan campur tangan manusia yang dahulunya merupakan hutan yang masih tejaga alaminya dan sekarang sudah banyak sekali pohon-pohonan yang sudah sengaja untuk ditebang, guna untuk pembangunan penginapan bagi wisatawan dengan kepentingan ekonomi. Sehingga terjadi perubahan keberadaan populasi hewan yang terdapat di lokasi hutan sekunder 
salah satu populasi hewan tersebut adalah gastropoda.

Berdasarkan survei awal, penulis menemukan gastropoda di dua habitat saja yaitu gastropoda yang hidup di air tawar dan gastropoda yang hidup di darat. Pada penelitian ini penulis hanya memfokuskan gastropoda yang hidup di darat. Pada umumnya gastropoda yang hidup di darat lebih dikenal dengan sebutan keong darat.

Berdasarkan kondisi lingkungan Taman Wisata Alam Telaga Warna yang telah mengalami perubahan secara bertahap dan terus menerus berpengaruh terhadap kondisi fisik dan faktor biotik. Hal tersebut sangat menentukan jenis keong darat di daerah tersebut. Dengan demikian perlu mengetahui keanekaragaman keong darat di Taman Wisata Alam Telaga Warna Puncak Bogor Jawa Barat.

\section{MATERI DAN METODE}

\section{Alat dan Bahan}

Alat dan bahan yang digunakan dalam melakukan penelitian di lapangan diantaranya adalah kamera Digital Canon, Meteran Gulung, GPS, Weather Meter, Tali Tambang, Alat tulis, Kertas Lebel, Botol Spesimen, Alkohol 70\%, buku identifikasi lapangan Keong Darat. Untuk penelitian di laboratorium menggunakan alat dan bahan diantaranya adalah mikroskop, pinset, ATK, kertas lebel, sarung tangan karet, alkohol $70 \%$. Penelitian ini bersifat deskriptif analitik, metode yang digunakan adalah purposive sampling adalah menentukan lokasi penelitian, kemudian memasang garis transek 100m.cara pengambilan sampel dengan meletakan kuadrat ukuran $2 \mathrm{~m}$ x $2 \mathrm{~m}$.

\section{Analisis Data}

Untuk mengetahui keanekaragaman jenis keong darat di Kawasan Taman Wisata Alam (TWA) Telaga Warna dengan menggunakan analisis data yaitu:

\section{Kelimpahan Relatif}

Kelimpahan relatif dihitung dengan rumus kelimpahan relatif menurut (Suin, 2003) sebagai berikut:

$$
\mathrm{KR} \text { jenis } \mathrm{A}=\frac{\mathrm{K} \text { Jenis } \mathrm{A}}{\text { jumlah } \mathrm{K} \text { Semua Jenis }} \mathrm{X}
$$

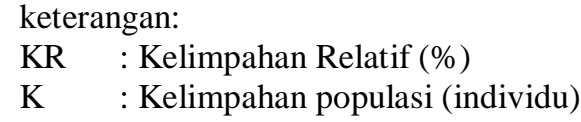

\section{Indeks Keanekaragaman}

Menurut Odum (1993) Keanekargaman jenis merupakan indeks yang menghubungkan antara jumlah spesies dan jumlah individu. Indeks keanekaragaman jenis menggunakan Indeks Shannon, sebagai berikut:

$$
\begin{gathered}
\mathrm{H}^{\prime}=-\sum \mathrm{pi} \ln \mathrm{pi} \\
\mathrm{Pi}=\frac{\text { jwmiah individu dalam setiap spesies }}{\text { jwmiah total individu }}
\end{gathered}
$$

Keterangan : $\quad \mathrm{H}^{\prime}=$ Indeks

$\mathrm{P}=$ Proposi Jenis ke- $1(\mathrm{Pi}=\mathrm{ni} / \mathrm{N})$

$\mathrm{Ni}=$ Jumlah individu dalam setiap spesies

$\mathrm{N}=$ Jumlah total individu

Kriteria indeks keanekaragaman:

$\mathrm{H}^{\prime}<1=$ keanekaragaman rendah

$\mathrm{H}^{\prime}=1-3=$ keanekaragaman sedang

$\mathrm{H}^{\prime}>3=$ keanekaragaman tinggi

\section{Indek Dominansi}

Dominansi jenis dihitung menggunakan indeks dominansi Simpson (Odum, 1993) sebagai berikut:

$$
\mathrm{C}=\Sigma(\mathrm{ni} / \mathrm{N})^{2}
$$

$$
\begin{aligned}
& \text { Keterangan: } \\
& \mathrm{C}=\text { indeks dominansi } \\
& \mathrm{ni}=\text { jumlah spesies suatu jenis } \\
& \mathrm{N}=\text { jumlah seluruh spesies }
\end{aligned}
$$

Kriteria indeks dominansi:

$\mathrm{C}<0.5=$ dominansi rendah

C $>0.5=$ dominansi tinggi 
Indeks Kesamaan Jenis (S)

$$
\mathrm{S}=\frac{2 C}{(a+b)}
$$

Keterangan:

$\mathrm{C}=$ Jumlah spesies dari spesies yang sama kedua sampel

$\mathrm{a}=$ Jumlah spesies pada habitat a

$\mathrm{b}=$ jumlah spesies pada habitat $\mathrm{b}$

Kriteria kesamaan jenis:

$>50 \%=$ kesamaan komunitas antara kedua habitat sama

$<50 \%=$ kesamaan komunitas antara kedua habitat tidak sama

\section{Indeks Kemerataan Jenis}

Untuk mengetahui kemerataan jenis-jenis keong darat dimasing-masing tipe habitat, rumus indeks kemerataan (E) diperoleh dari (Fachrul, 2007) yaitu:

$$
\mathrm{E}=\frac{H v}{\ln S}
$$

Keterangan:

$\mathrm{E}=$ Indeks Kemerataan Jenis

$\mathrm{H}^{\prime}=$ Indeks Keanekaragaman Jenis

$\mathrm{S}=$ Jumlah Jenis yang ditemukan

Kriteria indeks kemerataan spesies:

$\mathrm{E}=0$. kemerataan antar spesies rendah, artinya kekayaan individu yang dimiliki masingmasing spesies berbeda.

$\mathrm{E}=1$, kemerataan antar spesies relatif merata atau jumlahindividu Masing-masing spesies relatif sama.

\section{Indeks Sebaran Morisita}

Untuk mengetahui bagaimana pola sebaran populasi dalam ekosistem digunakan Indeks penyebaran Morisita menurut Krebs (1989):

$$
\mathrm{I}=\mathrm{n} \Sigma \mathrm{X}^{2}-\mathrm{N}: \mathrm{N}(\mathrm{N}-1)
$$

Keterangan:

I : Indeks Sebaran Morisita

$\mathrm{n}$ : Jumlah satuan pengambilan contoh

$\mathrm{N}$ : jumlah totsl individu

$\mathrm{X}$ : jumlah individu spesies pada pengambilan
Kriteria Sebaran Morisita:

I > 1: pola sebaran jenis individu bersifat mengelompok

I = 1: pola sebaran jenis individu bersifat acak

I $<1$ : pola sebaran jenis individu bersifat seragam

\section{HASIL}

Hasil penelitian yang ditemukan setelah dilakukan 3 kali pengulangan pada waktu yang berbeda adalah 7 famili pada waktu malam hari di Kawasan Taman Wisata Alam (TWA) dan 5 famili pada waktu pagi hari di Kawasan Taman Wisata Alam (TWA). Pada malam hari ditemukan 10 genus dan 11 spesies, dengan jumlah keseluruhan 336 individu. Sedangkan pada pagi hari ditemukan 5 genus dan 6 spesies, dengan jumlah keseluruhan 40 individu.

\section{Indeks Kelimpahan Relatif Keong Darat}

Tabel 1. Kelimpahan Jenis Relatif Keong Darat di (TWA) Malam hari

\begin{tabular}{lccc}
\hline \multicolumn{1}{c}{ Jenis } & $\begin{array}{c}\text { Hutan } \\
\text { Primer } \\
(\%)\end{array}$ & $\begin{array}{c}\text { Hutan } \\
\text { Sekunder } \\
(\%)\end{array}$ & $\begin{array}{c}\text { Sekitar } \\
\text { Danau } \\
(\%)\end{array}$ \\
\hline $\begin{array}{l}\text { Cyclophorus perdix } \\
\text { perdix }\end{array}$ & 18,84 & 0.00 & 0.00 \\
$\begin{array}{l}\text { Cyclophorus rafflesi } \\
\text { rafflesi }\end{array}$ & 0.00 & 0.82 & 0.00 \\
$\begin{array}{l}\text { Hemiplecta } \\
\text { humphreysiana }\end{array}$ & 17,39 & 12,39 & 1,42 \\
$\begin{array}{l}\text { Dyakia rumphii } \\
\text { Parmarion pupilaris }\end{array}$ & 18,84 & 29,75 & 20.54 \\
$\begin{array}{l}\text { Meghimatium } \\
\text { bilineatum }\end{array}$ & 0.00 & 0.00 & 78,08 \\
$\begin{array}{l}\text { Landouria monticolc } \\
\text { Pupina junghuhni }\end{array}$ & $2,90.14$ & 50.41 & 0.00 \\
$\begin{array}{l}\text { Helicarion albelus } \\
\text { Acrophaedusa }\end{array}$ & 11,59 & 3,30 & 0.00 \\
schepmani & 0.00 & 0.82 & 0.00 \\
$\begin{array}{l}\text { Aphidromus aticola } \\
\text { Ant }\end{array}$ & 0.00 & 0.82 & 0.00 \\
\hline
\end{tabular}


Dari hasil (Tabel 1) pada tiga lokasi yaitu Hutan Primer, Hutan Sekunder dan Sekitar Danau di Kawasan Taman Wisata Alam Telaga Warna Puncak Bogor Jawa Barat pada waktu malam hari, kelimpahan jenis Keong Darat di Lokasi Hutan Strata adalah Cyclophorus perdix perdix 18.84\%, Hemiplecta humphreysiana $17.39 \%$, Parmarion pupilaris $18.84 \%$, Dyakia rumphii 20.28\%, Helicarion albellus $11.59 \%$, Landouria monticola 10.14\%, Pupina junghuhni 2.90\%. Kelimpahan jenis Keong Darat di Lokasi Hutan Sekunder adalah Parmarion pupilaris 29,75\%, Helicarion albellus 3.30\%, Landouria monticola $50.41 \%$, Hemiplecta humphreysiana 12,39\%, Cyclophorus rafflesi rafflesi $0.82 \%$, Pupina junghuhni $1.65 \%$, Acrophaedusa schepmani $0.82 \%$, Amphidromus Aticola $0.82 \%$. Dan kelimpahan jenis Keong Darat di Lokasi Dekat Danau adalah Meghimatium bilineatum $78.08 \%$, Parmarion pupilaris $20.54 \%$, Hemiplecta humphreysiana1,42\%.

Tabel 2. Kelimpahan Relatif Jenis Keong Darat di (TWA) Pagi hari

\begin{tabular}{lccc}
\multicolumn{1}{c}{ Jenis } & $\begin{array}{c}\text { Hutan } \\
\text { Primer } \\
(\boldsymbol{\%})\end{array}$ & $\begin{array}{c}\text { Hutan } \\
\text { Sekunder } \\
(\%)\end{array}$ & $\begin{array}{c}\text { Sekitar } \\
\text { Danau } \\
(\boldsymbol{\%})\end{array}$ \\
\hline $\begin{array}{l}\text { Cyclophorus } \\
\text { perdix perdix }\end{array}$ & 11,12 & 7,69 & 0.00 \\
$\begin{array}{l}\text { Meghimatium } \\
\text { bilineatum }\end{array}$ & 0.00 & 0.00 & 20 \\
$\begin{array}{l}\text { Parmarion } \\
\text { pupilaris }\end{array}$ & 0.00 & 3,84 & 60 \\
$\begin{array}{l}\text { Dyakia } \\
\text { rumphii }\end{array}$ & 66,67 & 0.00 & 0.00 \\
$\begin{array}{l}\text { Helicarion } \\
\text { albelus }\end{array}$ & 22,23 & 84,61 & 0.00 \\
$\begin{array}{l}\text { Landouria } \\
\text { monticola }\end{array}$ & 0.00 & 3,84 & 20 \\
\hline
\end{tabular}

Berdasarkan hasil (Tabel 2) di atas pada tiga lokasi yaitu hutan primer, hutan sekunder dan sekitar danau di Kawasan Taman Wisata
Alam Telaga Warna Puncak Bogor Jawa Barat pada waktu pagi hari, kelimpahan jenis Keong Darat di Lokasi Hutan Primer adalah Dyakia rumphii 66,67\%, Cyclophorus perdix perdix $11,12 \%$, Helicarion albellus 22,23\%. Kelimpahan jenis Keong Darat di Lokasi Hutan Sekunder adalah Cyclophorus perdix perdix 7,69\%, Landouria monticola 3,84\%, Helicarion Albellus 84,61\%, Parmarion pupilaris 3,84\%. Kelimpahan jenis Keong Darat di Lokasi Sekitar Danau adalah parmarion pupilaris $60 \%$, Landouria monticola 20\%, meghimatium bilineatum $20 \%$.

\section{Indeks Keanekaragaman Keong Darat}

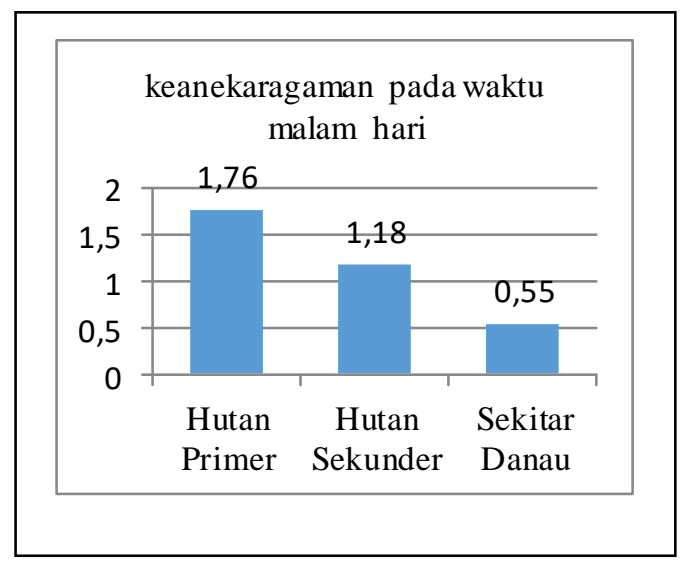

Gambar 1. Keanekaragaman jenis keong darat di (TWA) Telaga Warna

Gambar 1 di atas menunjukan setelah dilakukan perhitungan dengan rumus keanekaragaman jenis (Shannon-Wiener) didapati pada tiga lokasi yaitu Hutan Primer H' $=1.76$, Hutan Sekuner H' $=1.18$ dan Sekitar Danau H' = 0.55 di Kawasan Taman Wisata Alam Telaga Warna pada waktu malam hari.

Gambar 2 di bawah ini menunjukan keanekaragaman jenis Keong Darat pada waktu pagi hari yang telah dilakukan perhitungan dengan rumus (Shannon-Wienner) didapati dari tiga lokasi adalah Hutan Primer $\mathrm{H}^{\prime}=0.84$, Hutan Sekunder H'=0.52 dan Sekitar Danau H'=0.94 di Kawasan Taman Wisata Alam Telaga Warna Puncak Bogor Jawa Barat. 


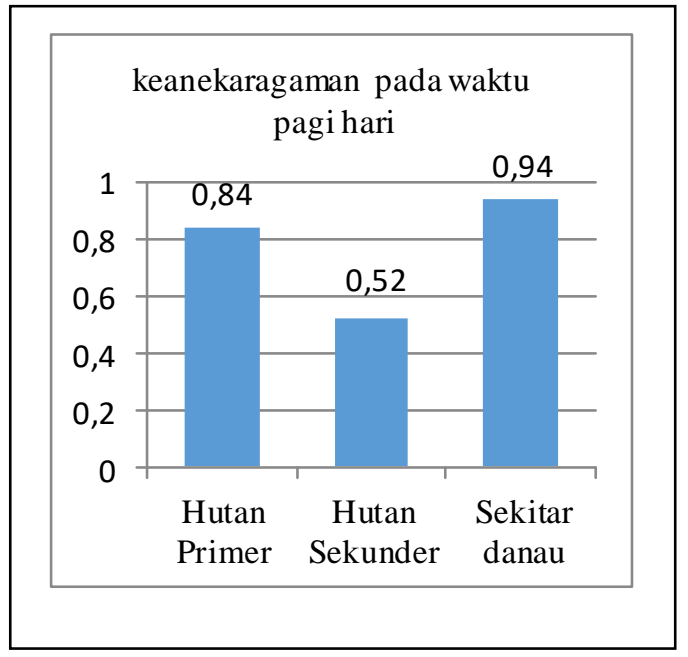

Gambar 2. Keanekaragaman Shannon-Wienner jenis keong darat di (TWA) Telaga Warna.

\section{Indeks Dominansi dan Indeks Kemerataan} Jenis Keong Darat

Tabel 3. Indeks Dominansi dan Indeks Kemerataan spesies.

\begin{tabular}{ccccccc}
\hline & \multicolumn{2}{c}{ L1 } & \multicolumn{2}{c}{ L2 } & \multicolumn{2}{c}{$\mathbf{L 3}$} \\
\cline { 2 - 7 } & $\mathbf{M}$ & $\mathbf{P}$ & $\mathbf{M}$ & $\mathbf{P}$ & $\mathbf{M}$ & $\mathbf{P}$ \\
\hline ( C) & 0.15 & 0.49 & 0.35 & 0.72 & 0.64 & 0.44 \\
(E) & 0.90 & 0.76 & 0.56 & 0.37 & 0.50 & 0.85 \\
\hline
\end{tabular}

Berdasarkan (Tabel 3) hasil perbandingan nilai Indeks dominansi dan Indeks kemerataan spesies dari tiga lokasi dengan waktu yang berbeda pada malam hari dan pagi hari dalam (Tabel 3). Dari hasil tabel menununjukan bahwa pada malam hari dominansi spesies tertinggi terdapat pada lokasi sekitar danau $\mathrm{C}=$ 0.64, dominansi terendah pada lokasi hutan primer $\mathrm{C}=0.15$ sedangkan pada pagi hari dominansi spesies yang tertinggi di lokasi hutan sekunder $\mathrm{C}=0.72$ dan yang terendah di lokasi sekitar danau yaitu $C=0.44$. Sedangkan indeks kemerataan yang tertinggi pada waktu malam hari pada lokasi hutan primer $\mathrm{E}=0.90$ dan yang terendah di lokasi dekat danau $\mathrm{E}=0.50$. Pada waktu pagi hari yang tertinggi di lokasi sekitar danau $\mathrm{E}=0.85$ dan terendah di lokasi hutan sekunder $\mathrm{E}=0.37$.

\section{Indeks Kesamaan Populasi Keong Darat}

Tabel 4. Indeks Kesamaan di Tiga Lokasi Pengamatan pada Malam Hari.

\begin{tabular}{|c|c|c|c|c|c|c|}
\hline \multirow{2}{*}{ Lokasi } & \multicolumn{2}{|c|}{ L1 } & \multicolumn{2}{|c|}{ L2 } & \multicolumn{2}{|c|}{$\mathbf{L 3}$} \\
\hline & M & $\mathrm{P}$ & M & $\mathrm{P}$ & $\mathrm{M}$ & $\mathrm{P}$ \\
\hline L1 & - & - & & & & \\
\hline L2 & 0.66 & 0.57 & - & & & \\
\hline $\mathbf{L 3}$ & 0.40 & 0.33 & 0.36 & 0.57 & - & - \\
\hline
\end{tabular}

Berdasarkan Tabel 4 didapatkan pada waktu malam hari tingkat kesamaan populasi antara lokasi hutan primer dan hutan sekunder sebesar 0.6. Kesamaan populasi pada lokasi dekat danau dan hutan primer sebesar 0.4 dan pada lokasi hutan sekunder dan sekitar danau kesamaan populasinya sebesar 0.3. Sedangkan nilai indeks kesaman populasi pada waktu pagi hari nilai yang didapatkan di lokasi hutan primer dan hutan sekunder sebesar 0.5. Di lokasi sekitar danau dan hutan primer 0.3 dan pada lokasi hutan sekunder dan dekat danau kesamaan populasi sebesar 0.5 .

\section{Pola Sebaran Keong Darat}

Tabel 5 di bawah ini menunjukan nilai hasil pola sebaran di kawasan TWA Telaga Warna pada lokasi hutan primer, hutan sekunder dan dekat danau mengalami distribusi fauna yang menyeragam yaitu 0.12 di hutan primer, $0.38 \mathrm{di}$ hutan sekunder dan 0.56 di dekat danau. Menurut indeks Morishita I $<1$ pola sebaran jenis seragam. Sedangkan pola sebaran keong darat di Kawaan Taman Wisata Alam Telaga Warna pada pagi hari memiliki Pola sebaran yang berbeda, di lokasi hutan primer dan sekitar danau yaitu 0.13 dan 0.02 menunjukan pada lokasi tersebut sebaran keong darat menyeragam sedangkan pada lokasi hutan sekunder 1,27 pola sebarannya berkelompok. 
Tabel 5. Pola sebaran keong darat di Kawasan TWA Telaga Warna

\begin{tabular}{|c|c|c|c|c|c|c|}
\hline \multirow{3}{*}{ Morisita } & \multicolumn{2}{|c|}{ L1 } & \multicolumn{2}{|c|}{ L2 } & \multicolumn{2}{|c|}{ L3 } \\
\hline & M & $\mathrm{P}$ & $\mathrm{M}$ & $\mathrm{P}$ & M & $\mathrm{P}$ \\
\hline & 0.12 & 0.13 & 0.38 & 1,27 & 0.56 & 0.02 \\
\hline 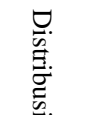 & 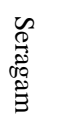 & 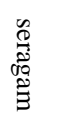 & 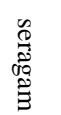 & $\begin{array}{l}\frac{\pi}{O} \\
\stackrel{0}{O} \\
\frac{0}{0}\end{array}$ & 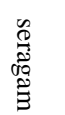 & 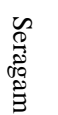 \\
\hline
\end{tabular}

\section{Data Fisik Lingkungan Keong Darat yang diambil saat Penelitian}

Data fisik lingkungan diambil pada saat menemukan jenis keong darat di ketiga lokasi yaitu hutan primer, hutan sekunder dan sekitar danau pada Kawasan Taman Wisata Alam (TWA) Telaga Warna dan pada waktu yang berbeda yaitu malam dan pagi hari. Data fisik yang diukur antara lain suhu dan kelembaban. Data hasil pengukuran lingkungan keong darat di ketiga lokasi penelitian dengan waktu yang berbeda dapat dilihat pada tabel dibawah ini.

Tabel 6. Tabel 6. Data Fisik di ketiga lokasi (TWA) Telaga Warna

\begin{tabular}{ccccc}
\hline & Lokasi & $\begin{array}{c}\text { Suhu } \\
\left({ }^{\circ} \mathrm{C}\right)\end{array}$ & $\begin{array}{c}\text { Kelembaba } \\
\mathrm{n} \\
(\%)\end{array}$ & $\begin{array}{c}\text { Ketinggia } \\
\mathrm{n} \\
(\mathrm{mdpl})\end{array}$ \\
\hline L1 & Malam & 25.0 & 76.6 & 1470 \\
& Pagi & 27.4 & 70.5 & 1450 \\
L2 & Malam & 25.6 & 75.9 & 1477 \\
& Pagi & 27.2 & 68.3 & 1437 \\
L3 & Malam & 24.2 & 80.1 & 1472 \\
& pagi & 26.4 & 69.0 & 1443 \\
\hline
\end{tabular}

\section{PEMBAHASAN}

\section{Kelimpahan Jenis Relatif}

Dari hasil perhitungan Kelimpahan jenis keong darat di Kawasan Taman Wisata Alam (TWA) pada malam hari (Tabel 1) kelimpahan yang tertinggi pada lokasi hutan primer adalah jenis Dyakia rumphii dengan nilai komposisi relatif $20.28 \%$ jenis ini hanya ditemukan pada lokasi hutan primer. Dan di lokasi hutan sekunder kelimpahan jenis tertinggi pada jenis Landouria monticola dengan nilai sebesar $50.41 \%$ jenis ini hanya ditemui di lokasi hutan primer dan hutan sekunder. Sedangkan pada lokasi sekitar danau kelimpahan jenis yang tertinggi adalah Meghimatium bilineatum dengan nilai 78,08\% jenis ini hanya terdapat di lokasi sekitar danau. ketika pagi hari kelimpahan relatif (Tabel 2) yang tertinggi di lokasi hutan primer adalah jenis Dyakia rumphii dengan nilai $66,67 \%$ jenis ini memiliki komposisi relatif yang tinggi karena jenis ini terdapat pada pagi dan malam hari. Karena jenis ini menyukai tempat yang lembab dan suhu dingin, ketika pagi hari jenis ini berada di dalam serasah yang ditemukan di lantai hutan. Pada lokasi hutan sekunder memiliki kelimpahan relatif jenis tertinggi adalah jenis Helicarion albelus dengan nilai sebesar $84,61 \%$ sedangkan di lokasi sekitar danau kelimpahan relatif tertinggi adalah jenis Parmarion pupilarissebesar $60 \%$. Kelimpahan relatif jenis yang tertinggi pada setiap lokasi tersebut berkaitan erat oleh faktor habitat, suhu dan kelembaban ketika kebutuhan hidupnya yang amat spesifik menentukan tempat yang sesuai maka dapat berkembang biak dengan baik, mengalahkan spesies-spesies lainnya (Heryanto, 2013).

\section{Indeks Kesamaan Jenis}

Indeks kesamaan jenis di Kawasan Taman Wisata Alam (TWA) pada malam hari (Tabel 4) memiliki tingkat kesamaan tertinggi di lokasi hutan sekunder dengan hutan primer sebesar 0.66 memiliki kesamaan $66 \%$ jenis yang sama dan terendah indeks kesamaan pada lokasi dekat danau dengan hutan primer sebesar 0.40 memiliki kesamaan $40 \%$ jenis yang sama. Hal tersebut dikarnakan lokasi pada sekitar danau yang terbuka sehingga perbedaan suhu cenderung lebih tinggi dan kelemababan lebih rendah berpengaruh dengan kesamaan komunitas spesies keong darat. Sedangkan Pada pagi hari indeks kesamaan jenis tertinggi pada lokasi hutan sekunder dengan hutan primer 0.57 sehingga memiliki kesamaan 57\% sedangkan kesamaan jenis terendah pada lokasi dekat danau dan hutan primer yaitu 0.33 atau memiliki kesamaan $33 \%$. Pada lokasi hutan sekunder dengan hutan primer 
memiliki nilai kesamaan komunitas yang sama yaitu 0.57 atau $57 \%$ hal tersebut memungkinkan terjadi kesamaan komunitas oleh faktor suhu antara kesamaan di kedua tempat kisaran 26,4$26,7^{\circ} \mathrm{C}$ dan cuaca pada waktu penelitian cerah sehingga didapati kesamaan komunitas yang sama.

\section{Kemerataan dan Dominansi Jenis Keong Darat}

Kemerataan dan dominansi pada ketiga lokasi di hutan primer, hutan sekunder dan sekitar danau pada malam hari memiliki nilai kemerataan $\mathrm{E}=0.90-0.50$ dan dominansi $\mathrm{C}=0.15-0.64$ sedangkan pada waktu pagi hari nilai kemerataan $\mathrm{E}=0.37-0.8$ dan dominansi $\mathrm{C}=0.44-0.72$. Dominansi spesies berpengaruh terhadap kemerataan jenis, indeks kemerataan berkisar antara 0-1. Indeks kemerataan mendekati nol, berarti dalam ekosistem tersebut ada kecenderungan terjadi dominansi spesies yang disebabkan oleh adanya ketidakstabilan faktor-faktor lingkungan dan populasi (Gundo Meria, 2010). Bila indeks kemerataan mendekati satu, maka jumlah individu tiap spesies relatif sama.

\section{Keanekaragaman Jenis Keong Darat}

Keanekargaman keong darat tertinggi pada waktu malam hari di lokasi hutan primer dari ketiga lokasi dengan nilai $\mathrm{H}^{\prime}=$ 1.76 Keanekaragaman terendah pada lokasi dekat danau dengan nilai $\mathrm{H}^{\prime}=0.55$ disebabkan memiliki dominansi yang tertinggispesies yang mendominansi di dekat danau yaitu Meghimatium bilineatum. Keanekargaman spesies pada pagi hari. Keanekargaman keong darat tertinggi pada waktu pagi hari di lokasi dekat danau dengan nilai $\mathrm{H}^{\prime}=0.94$. Sedangkan keanekaragaman jenis keong darat yang terendah pada pagi hari di lokasi hutan sekunder dengan nilai H' $=0.52$. Keanekaragaman jenis keong darat pada ketiga lokasi tersebut pada waktu malam dan pagi hari di lokasi hutan primer dan sekitar danau (H') yaitu berkisar 0.941,76 yang dikatagorikan keanekargaman sedang karena berada di antara 1 dan $3 \mathrm{H}^{\prime}=$
1-3. Keanekaragaman jenis keong darat dapat dilihat kelimpahan jenis paling banyak ditemui pada malam hari, di lokasi hutan primer dan sekunder. Faktor yang mempengaruhi keanekaragaman adalah habitat, suhu dan kelembaban (Belhiouani, El-Okki, M.E., Afri-Mehennaoui, \& Sahli, 2019). Tumpukan daun di atas serasah dapat membentuk lapisan penahan suhu malam dengan siang di luar serasah tidak mempengaruhi suhu di dalam serasah (Villeneuve, Thornhill, \& Eales, 2019). Jarangnya vegetasi membuat serasah yang di lantai hutan sedikit sehingga membuat dua hal yang tidak baik bagi kehidupan keong yaitu sedikitnya perlindungan dan sedikitnya pasokan makanan.

\section{Pola Sebaran Keong Darat}

Pola sebaran keong darat di Kawasan Taman Wisata Alam Telaga Warna pada malam hari setelah dihitung dengan rumus Morisita hasilnya adalah sama pola sebarannya yaitu distribusi menyeragam. Penyebaran seragam dapat terjadi di mana persaingan di antara individu sangat keras di mana terdapat antagonisme positif yang mendorong pembagian ruang yang sama (Gao et al., 2017). Sedangkan pada waktu pagi hari terlihat distribusi berkelompok di lokasi hutan sekunder dengan nilai sebesar 1.27. Hal tersebut disebabkan kondisi lingkungan jarang yang seragam, meskipun pada area yang sempit. Perbedaan kondisi tanah dan iklim pada suatu area akan menghasilkan perbedaan dalam habitat yang penting bagi setiap organisme yang ada di dalamnya, karena suatu organisme akan ada pada suatu area yang faktor-faktor ekologinya tersedia dan sesuai bagi kehidupannya, distribusi berkelompok dapat meningkatkan unsur hara, makanan, ruang dan cahaya (Indriyanto, 2006). Sedangkan 
pada lokasi hutan primer dan sekitar danau distribusi keong darat menyeragam.

\section{KESIMPULAN}

Teridentifikasi keong darat terdapat 336 individu yang dapat dikelompokan adalah 7 Famili, 10 genus, 11 Spesies pada waktu malam hari, sedangkan pada waktu pagi hari terdapat 40 individu, 5 Famili, 6 Genus 6 Spesies.

Keanekaragaman jenis keong darat di Kawasan Taman Wisata Alam Telaga Warna pada waktu malam hari yaitu di lokasi hutan primer $\mathrm{H}^{\prime}=1.76$ dan terendah keanekaragaman jenis keong darat di lokasi dekat danau H' $=0.55$ sedangkan pada pagi hari keanekaragaman jenis keong darat tertinggi di lokasi dekat danau $\mathrm{H}^{\prime}=$ 0.94 dan terendah keaneragaman jenis keong darat pada lokasi hutan sekunder dengan nilai $\mathrm{H}^{\prime}$ $=0.52$.

\section{UCAPAN TERIMA KASIH}

Terima kasih kepada Kementerian Riset, Teknologi, dan Pendidikan Tinggi Republik Indonesia untuk bantuan dana melalui hibah PUPT dengan kontrak nomor 2710 UN2.R3.1/HKP05.00/2017 atas nama Dr. Noviar Andayani sehingga dapat mendanai penelitian Akumulasi Akumulasi Timbal dan Kadmium pada Eclipta prostrata, Synedrella nodiflora, dan Tridax procumbens yang Tumbuh Liar di Sisi Jalan Raya Bogor.

\section{REFERENSI}

Belhiouani, H., El-Okki, M.E., Afri-Mehennaoui, F., \& Sahli, L. (2019). Terrestrial gastropod diversity, distribution and abundance in areas with and without anthropogenic disturbances, Northeast Algeria. Biodiversitas., 20(1). https://doi.org/10.13057/biodiv/d200128

Cunha, C. M., \& Migotto, A. E. (2015). Rediscovery of Gastropteron chacmol (Gastropoda: Gastropteridae) on the Brazilian coast. Marine Biodiversity, $\quad 46(1), \quad 1-2$. https://doi.org/doi:10.1007/s12526-015-0312-1

Fachrul, M. F. (2007). Metode Sampling Ekologi.
Jakarta: Bumi Aksara.

Gao, X., Li, Y., Li, X., Wu, F., Song, C., \& Liu, Y. (2017). The response and osmotic pressure regulation mechanism of Haliotis discus hannai (Mollusca, Gastropoda) to sudden salinity changes. Hydrobiologia, 795(1), 181-198. https://doi.org/10.1007/s10750-017-3129-z

Gundo Meria, T. (2010). Kerapatan Keanekaragaman dan Pola Penyebaran Gastropoda Air Tawar di Perairan Danau Poso. Jurnal Media Litbang Sulteng.

Heryanto, H. (2012). Ekologi Gunung Slamet Geologi, Klimatologi Biodiversitas dan Dinamika Sosial. Jakarta: LIPI Press.

Heryanto, H. (2013). Keanekargaman dan Kepadatan Gastropoda Terrestrial di Perkebunan Bogorejo Kecamatan Gedongtataan Kabupaten Pesawaran Provinsi Lampun. Jurnal Zoo Indonesia., 3, 223-233.

Indriyanto, I. (2006). Ekologi Hutan. Jakarta: Bumi Aksara.

Jeffery, P. (2001). Suprageneric classification of class Gastropoda. London: The Natural History Museum.

Kozminsky, E. V. (2012). Effects of environmental and biotic factors on the fluctuations of abundance of Littorina obtusata (Gastropoda: Littorinidae). Hydrobiologia, 706(1), 81-90. https://doi.org/10.1007/s10750-012-1418-0

Manutchehr-Danai, M. (2009). Dictionary of Gems and Gemology. https://doi.org/10.1007/978-3540-72816-0

Suin, N. M. (n.d.). Ekologi Hewan Tanah. Jakarta: Bumi Aksara ITB

Villeneuve, A. R., Thornhill, I., \& Eales, J. (2019). Upstream migration and altitudinal distribution patterns of Nereina punctulata (Gastropoda: Neritidae) in Dominica, West Indies. Aquatic Ecology, 53(2), 205-215. https://doi.org/10.1007/s10452-019-09683-7 